\section{Use of sedation tech- niques during local and regional anaesthesia}

The availability of improved sedative drugs and techniques has made it possible to perform an ever-increasing variety of surgical procedures under local or regional anaesthesia (Table I). The most popular anaesthetic techniques involve local infiltration of the operative field, intravenous regional anaesthesia, peripheral nerve blocks, and central neuroaxis blockade (e.g., spinal and epidural blocks). The advantages of these local anaesthetic techniques include preservation of protective airway reflexes, residual postoperative analgesia, and avoidance of the side effects associated with general anaesthesia (e.g., candiovascular and respiratory depression, nausea, vomiting, confusion and drowsiness). Use of peripheral nerve block techniques or local anaesthetic infiltration with intravenous sedative medications (e.g., midazolam, propofol) can provide improved recovery profiles with less postoperative pain and emesis compared with central neuroaxis blockade or general anaesthetic techniques. ${ }^{1-3}$

Surgical procedures performed under local anaesthesia can be uncomfortable for patients for a variety of reasons. Firstly, the subcutaneous injection of local anaesthetic solution is often painful, especially when multiple injections are required (e.g., cosmetic surgery). Secondly, traction on "deep" structures and the need for patients to remain immobile for prolonged periods of time on a hard, narrow operating table may also cause significant discomfort. Finally, many patients find the operating room environment and the concept of being awake and aware during surgery extremely anxiety-provoking. For these reasons, local anaesthetic techniques are often supplemented with adjunctive drugs to provide amnesia, anxiolysis, sedation and systemic analgesia. Sedative and analgesic drugs are also used to enhance patient comfort during painful diagnostic and therapeutic procedures (e.g., endoscopy, radiotherapy, imaging techniques, lithotripsy). Situations in which adjunctive sedative and analgesic medications are administered to a patient by an anaesthetist, with or without local anaesthetic infiltration, are known as monitored anaesthesia care (MAC).

The degree of intraoperative sedation provided should be titrated to meet the needs of the individual patient and is influenced by the type of procedure being performed. In addition, the patient's anxiety level may be reduced by a thorough preoperative explanation of the anticipated procedure, ongoing verbal communication during the operation, low levels of visual and auditory stimuli in the operating room, and by keeping the patient warm and covered during the surgical procedure. Incisional pain should be treated by the use of local anaesthetic infiltration or a field block. However, opioid and non-opioid analgesics are frequently administered in combination with sedative medication to supplement local anaesthesia in order to block painful sensations remote from the operative site. ${ }^{4}$ In achieving adequate patient comfort and sedation, it is important to avoid compromising patient safety. Excessive sedative medication can interfere with the patient's ability to talk and leave their airway unprotected and thereby increase the risk of aspiration-related complications. Supplemental oxygen is strongly recommended when adjunctive medications are administered to avoid haemoglobin oxygen desaturation due to depression of central respiratory drive or upper airway obstruction. ${ }^{5-7}$ Furthermore, the usual monitoring devices and emergency resuscitation equipment should be immediately available.

\section{Choice of sedative agents}

The centrally active adjunctive drugs available to optimize operating conditions for both the patient and the surgeon include benzodiazepines, opioid (narcotic) and nonopioid (nonsteroidal antiinflammatory drugs) analgesics, and sub-anaesthetic doses of sedative-hypnotics (e.g., barbiturates, etomidate, propofol, and ketamine). In addition, a wide variety of routes of administration (e.g., oral, transmucosal, parenteral, and inhaled) are available to administer adjuvants to patients receiving local or regional anaesthesia. However, the oral route is limited by the delayed onset of clinical effects, as well as by the lack of precise control over the resulting level of sedation. While inhalational techniques avoid many of these problems, the pungent smell of the available volatile agents, as well as the tendency of these drugs to increase postoperative nausea and vomiting, make them unacceptable

From the Department of Anesthesiology and Pain Management, University of Texas Southwestern Medical Center, 5323 Harry Hines Boulevard, Dallas, Texas 752359068. 
TABLE I Surgical procedures that can be performed under local or regional anaesthesia

\begin{tabular}{|c|c|}
\hline $\begin{array}{l}\text { Procedures utilizing } \\
\text { sedation with or } \\
\text { without topical } \\
\text { anaesthesia }\end{array}$ & $\begin{array}{l}\text { Upper gastrointestinal flexible endoscopy } \\
\text { Lower intestinal endoscopy } \\
\text { Flexible bronchoscopy } \\
\text { Extracorporeal shock-wave lithotripsy } \\
\text { ransvaginal ovum retrieval and other } \\
\text { IVF procedures } \\
\text { Radiotherapy and paediatric imaging } \\
\text { techniques }\end{array}$ \\
\hline $\begin{array}{l}\text { Procedures utilizing } \\
\text { sedation and local } \\
\text { anaesthetic infiltration } \\
\text { (or local anaesthetic } \\
\text { blocks) }\end{array}$ & $\begin{array}{l}\text { Angiography, pacemaker insertion, } \\
\text { vascular access catheters, venous filter } \\
\text { placement } \\
\text { Dental extractions and conservations } \\
\text { Cataract and other ocular surgery } \\
\text { Excisions of body surface masses and } \\
\text { lesions } \\
\text { Sinus surgery and polypectomy } \\
\text { Arthroscopy, carpal tunnel repair, minor } \\
\text { peripheral orthopaedic procedures } \\
\text { Circumcision, herniorrhaphy, varicose } \\
\text { vein surgery } \\
\text { Septorhinoplasty, face lifts and other } \\
\text { cosmetic surgical procedures } \\
\text { Vasectomy and orchiopexy } \\
\text { D\&C and perineal surgery }\end{array}$ \\
\hline $\begin{array}{l}\text { Procedures utilizing } \\
\text { sedation and regional } \\
\text { anaesthesia }\end{array}$ & $\begin{array}{l}\text { Cystoscopy, transurethral resection of } \\
\text { tumors and prostate } \\
\text { Arthroscopy and peripheral orthopaedic } \\
\text { procedures } \\
\text { D\&C, vaginal hysterectomy and repairs, } \\
\text { perineal surgery } \\
\text { Herniorrhaphy, EUA, } \\
\text { haemorrhiodectomy }\end{array}$ \\
\hline
\end{tabular}

to many patients. Furthermore, trace concentrations of inhaled agents can pollute the operating room environment, with resultant health hazards to medical and surgical personnel. Although transmucosal administration may become more popular in the future (with the recent FDA approval of the fentanyl Oralette delivery system), the intravenous route is the most popular approach at the present time. An understanding of the pharmacological and physiological effects of the commonly used sedative-hypnotic, anxiolytic and analgesic drugs is essential in order to achieve optimal surgical conditions and acceptable patient outcome when using sedation-based techniques. Since anaesthetic and analgesic medications from two or more drug groups are often combined, the possibility of adverse drug interactions must also be considered. ${ }^{\text {? }}$

\section{Sedative-hypnotic medications}

\section{Benzodiazepines}

All benzodiazepines have the ability to produce anxioly- sis, as well as varying degrees of amnesia and sedation. Benzodiazepine-induced central nervous system (CNS) depression is dose-dependent and can vary from minimal sedation to hypnosis (or unconsciousness). The prototypic benzodiazepine compound, diazepam, has a long elimination half-life (i.e., $24-48 \mathrm{hr}$ ), which may result in delayed recovery and a "hangover" sensation after surgery. For example, a diazepam dose of $0.2-0.4 \mathrm{mg} \cdot \mathrm{kg}^{-1}$ iv can impair driving skills for more than ten hours and may prolong recovery to a greater extent than general anaesthesia. ${ }^{8,9}$ The effects of diazepam are even further prolonged in the elderly, a population in whom local and regional techniques are frequently utilized. Resedation after an initial period of recovery is also a possibility due to the formation of active metabolites and enterohepatic recirculation. This is particularly undesirable for ambulatory patients since it may occur following discharge from the surgical facility. Finally, diazepam is insoluble in water, requiring organic solvents (e.g., propylene glycol) to produce a stable intravenous solution. Use of these solvents can result in a high incidence of venoirritation and phlebitis, although this may be reduced by using diazepam in the lipid emulsion (Diazemuls).

Midazolam is a more popular parenteral benzodiazepine because it is water soluble and does not cause pain on injection or venoirritation. ${ }^{10}$ Midazolam is a more rapid-acting benzodiazepine than diazepam with a relatively short elimination half-life (2-4 hr) and no active metabolites or enterohepatic recirculation, thereby permitting a more predictable recovery after brief procedures. In comparison with diazepam, midazolam has a steeper dose-response curve (Figure 1) and therefore requires careful intravenous titration to the desired clinical end-points to minimize side effects resulting from inadvertent overdosage. ${ }^{10}$ The effects of aging and pre-existing medical conditions can enhance the patient's sensitivity to midazolam and increase interpatient pharmacodynamic variability. In most studies, midazolam has a more rapid onset of clinical effect than diazepam and also produces more profound perioperative amnesia, anxiolysis and sedation. ${ }^{10}$ Although full recovery from the sedative effects of midazolam is generally more rapid than after diazepam administration, large doses of midazolam $(0.2$ $\mathrm{mg} \cdot \mathrm{kg}^{-1}$ ) can result in prolonged postoperative sedation. ${ }^{11}$

\section{Ketamine}

Ketamine is a phencyclidine derivative which can produce so-called "dissociative" sedative or anaesthetic states. ${ }^{12} \mathrm{Al}-$ though subhypnotic doses of ketamine can provide for a useful degree of sedation and amnesia during local or regional anaesthesia, it is the analgesic-like properties of ketamine which are of greatest benefit to the patient. Ke- 


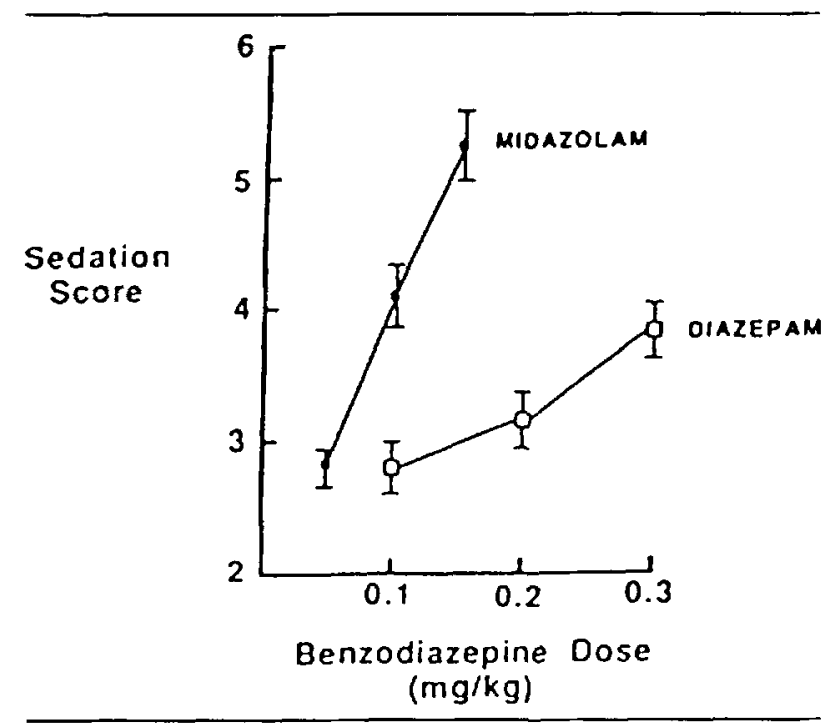

FIGURE 1 Relationship between the sedation score ( 2 = awake/ relaxed to $6=$ asleep/ unarousable) and the initial dose of midazolam or diazepam. Values represent means \pm SEM. Reproduced from White et al. ${ }^{10}$ with permission.

tamine, $0.25-0.75 \mathrm{mg} \cdot \mathrm{kg}^{-1} i v$ was associated with satisfactory patient comfort during the injection of large volumes of dilute local anaesthetic solutions for plastic surgery procedures. ${ }^{10}$ In addition, ketamine can provide supplemental analgesia in the event of an incomplete central neuroaxis block. The analgesia resulting from low doses of ketamine tends to be achieved in the absence of clinically important respiratory depression.

When ketamine is used in isolation, there is a high incidence of emergency phenomena and other excitatory side effects. ${ }^{13}$ However, these undesirable effects can be minimized by administering ketamine in conjunction with a benzodiazepine or other sedative-hypnotic drugs. ${ }^{14}$ In addition to enhancing sedation and amnesia, benzodiazepines attenuate the cardiostimulatory effects of ketamine, resulting in excellent cardiorespiratory stability. ${ }^{15}$ Following midazolam sedation, a ketamine infusion of 25 $\mu \mathrm{g} \cdot \mathrm{kg}^{-1} \cdot \mathrm{min}^{-1}$ gave effective sedation and analgesia during immersion lithotripsy. ${ }^{16}$ However, a high incidence of disruptive movements and side effects in the early recovery period (e.g., restlessness, dreaming, confusion) limits its clinical usefulness for this procedure. Furthermore, postoperative recovery and discharge times may be considerably delayed after brief outpatient procedures compared to alternative sedative techniques. Analogous to the earlier successful experience with a thiopentoneketamine combination, ${ }^{15}$ the use of ketamine in combination with propofol is increasing in popularity at the present time.
Propofol

Intravenous anaesthetics have been infused in subhypnotic doses to produce varying degrees of sedation. ${ }^{17}$ Typical drug and dosage regimens include thiopentone, 3-9 $\mathrm{mg} \cdot \mathrm{min}^{-1}$, methohexitone, $1-3 \mathrm{mg} \cdot \mathrm{min}^{-1}$, midazolam $0.06-0.18 \mathrm{mg} \cdot \mathrm{min}^{-1}$, etomidate, $0.2-0.6 \mathrm{mg} \cdot \mathrm{min}^{-1}$, and propofol $2-5 \mathrm{mg} \cdot \mathrm{min}^{-1}$. However, the use of relatively long-acting CNS depressant drugs can result in poor control of the hypnotic level and delayed recovery from the sedative effects. In contrast, the rapid redistribution and short elimination half-life of propofol results in a rapid recovery from the effects of a single bolus dose, as well as following a continuous infusion. Propofol's rapid onset and brief duration of action ensures prompt responsiveness to changes in its infusion rate, with optimal titration achieved by using a variable-rate infusion.

In 1987, Mackenzie and Grant administered propofol at an infusion rate of $3.8 \mathrm{mg} \cdot \mathrm{kg}^{-1} \cdot \mathrm{hr}^{-1}$ to patients undergoing lower limb surgery with spinal anaesthesia. ${ }^{18}$ At this relatively high dose, patients were asleep but arousable to command, and could easily be maintained at the desired level of sedation by varying the infusion rate. Within four minutes of discontinuing the infusion, patients were awake and quickly became "clearheaded." The authors also commented on the ease with which the transition to general anaesthesia could be achieved if the operation became more extensive than originally planned. In a follow-up study, these investigators compared a similar infusion rate of propofol with that of midazolam $(0.27$ $\left.\mathrm{mg} \cdot \mathrm{kg}^{-1} \cdot \mathrm{hr}^{-1}\right)$ as supplements to spinal anaesthesia. ${ }^{19}$ Comparable sedation was achieved with both drugs. However, after discontinuing the sedative infusions, patients receiving propofol were awake within two minutes compared with nine minutes after midazolam. Finally, White and Negus found that a propofol infusion allowed greater accuracy in titration of the sedative effect compared to a midazolam infusion during surgery performed under local or regional anaesthesia. ' The use of propofol reduced the incidence of "over" sedation and also resulted in decreased levels of postoperative sedation, drowsiness, confusion, clumsiness and amnesia than midazolam (Figure 2). In contrast to propofol, midazolam was associated with considerable impaired cognitive function for up to two hours postoperatively.

Low-dose propofol infusions have also been used as adjuncts to local infiltration anaesthesia in patients undergoing central venous line placement, ${ }^{20}$ oral surgery, ${ }^{21}$ and superficial surgical procedures, including breast biopsies and herniorrhaphies. ${ }^{1,4}$ Both early and intermediate recovery were superior following propofol than after midazolam ${ }^{1,20}$ or diazepam. ${ }^{21}$ Ferrari and Donlon compared bolus injections of propofol, $0.5 \mathrm{mg} \cdot \mathrm{kg}^{-1}$, with midazolam, $0.02 \mathrm{mg} \cdot \mathrm{kg}^{-1}$, and methohexitone, 0.45 

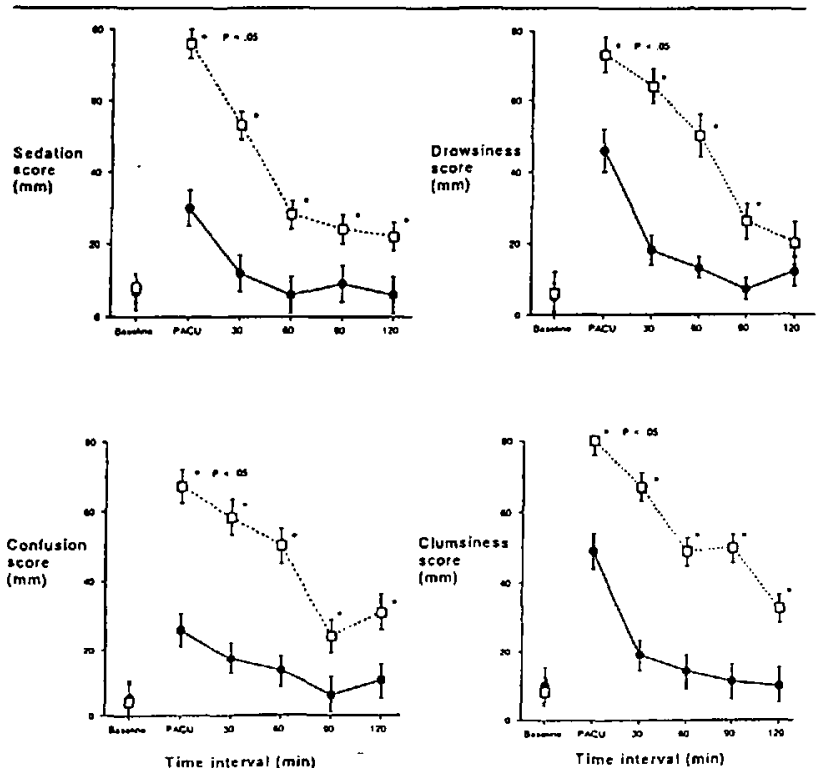

FIGURE 2 Perioperative sedation, drowsiness, confusion, and clumsiness visual analogue scores for patients receiving either midazolam (open squares) or propofol (solid circles) during surgery under local or regional anaesthesia. Values represent medians \pm SEM. Reproduced from White and Negus ${ }^{1}$ with permission. ${ }^{*} P<0.05$, from the propofol group.

$\mathrm{mg} \cdot \mathrm{kg}^{-1}$, for sedation during retrobulbar or peribulbar blocks for ophthalmological procedures. ${ }^{22}$ Patients receiving propofol had the lowest incidence of awareness during injection of the local anaesthetic block, and also experienced more satisfactory sedation during the remainder of the surgical procedure. Propofol is particularly beneficial for ophthalmological procedures because of its sedative properties, as well as its ability to decrease intraocular pressure and postoperative nausea. Propofol sedation can also provide satisfactory conditions when used for upper gastrointestinal endoscopic procedures. ${ }^{23}$ Highly acceptable conditions for these diagnostic procedures, as well as effective amnesia and rapid recovery, were achieved by infusing propofol at $4.3 \mathrm{mg} \cdot \mathrm{kg}^{-1} \cdot \mathrm{hr}^{-1}$. Patterson $e t$ al. reported a more rapid recovery and reduced hangover from propofol than after midazolam when these agents were administered during upper gastrointestinal endoscopic procedures. ${ }^{24}$

Propofol appears to be associated with a very low incidence of undesirable side effects when used in sedative doses. ${ }^{25}$ Use of propofol is rarely associated with excitatory phenomena or involuntary movements, and results in a low incidence of postoperative nausea and vomiting. Of particular importance, low-dose propofol infusions have very little depressant effect on cardiovascular or respiratory variables. ${ }^{26}$ Several investigators have commented upon the weak amnesia provided by subhypnotic
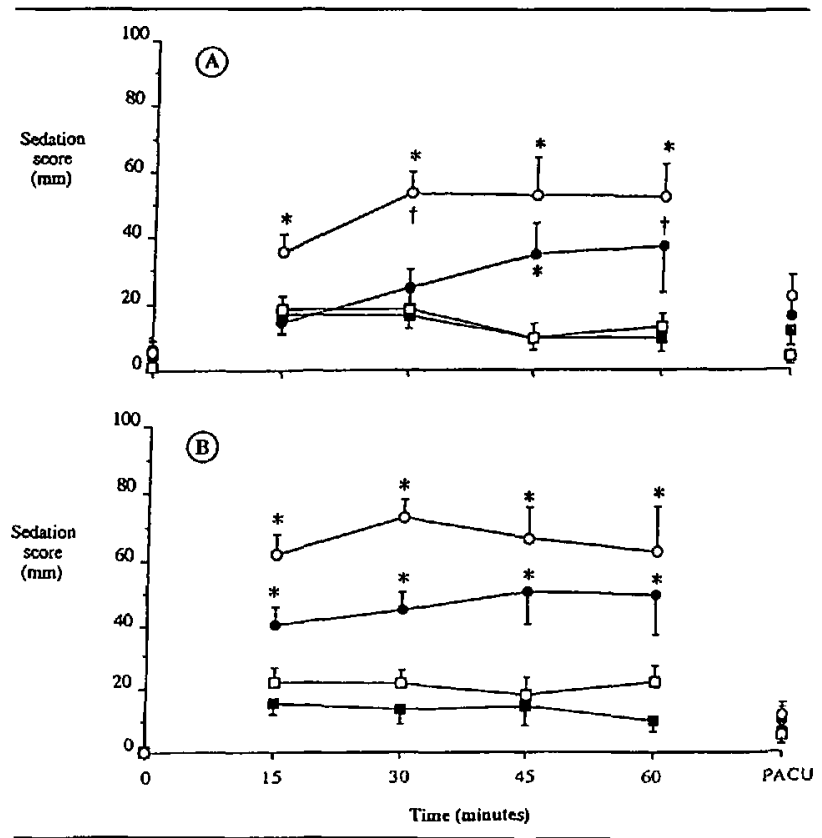

FIGURE 3 Sedation visual analogue scores recorded by patients (A) and by a blinded observer (B) before (time 0 ), during and after (PACU) sedation with propofol. Patients received propofol, $0.2 \mathrm{mg} \cdot \mathrm{kg}^{-1}$ and $0.5 \mathrm{mg} \cdot \mathrm{kg}^{-1} \cdot \mathrm{hr}^{-1}$ (Group 1; solid squares); $0.4 \mathrm{mg} \cdot \mathrm{kg}^{-1}$ and $1 \mathrm{mg} \cdot \mathrm{kg}^{-1} \cdot \mathrm{hr}^{-1}$ (Group 2, open squares); $0.5 \mathrm{mg} \cdot \mathrm{kg}^{-1}$ and $2 \mathrm{mg} \cdot \mathrm{kg}^{-1} \cdot \mathrm{hr}^{-1}$ (Group 3; solid circles); and $0.7 \mathrm{mg} \cdot \mathrm{kg}^{-1}$ and $4 \mathrm{mg} \cdot \mathrm{kg}^{-1} \cdot \mathrm{hr}^{-1}$ (Group 4; open circles). Values represent means \pm SEM. Reproduced from Smith $e t$ al. ${ }^{27}$ with permission. $* P<0.05$, from Group $1 ; \uparrow P<0.05$, from 15 min value in same group.

doses of propofol compared with that after benzodiazepines. 1,19,20,27 Smith et al. administered four different bolus-infusion regimens to patients undergoing urological surgery with regional anaesthesia. ${ }^{27}$ Sedation increased progressively with propofol infusion rates of $0.5,1,2$ and $4 \mathrm{mg} \cdot \mathrm{kg}^{-1} \cdot \mathrm{hr}^{-1}$ (Figure 3). Amnesia (or inability to recall a picture stimulus) during and immediately after the operation was not evident in the two low-dose propofol groups. However, at the two highest propofol dose levels, only $65 \%$ and $18 \%$ of the patients had intraoperative recall. Moreover, the low incidence of postoperative amnesia with propofol (vs midazolam) is advantageous after ambulatory surgery.

\section{Analgesic adjuvants}

\section{Opioid analgesics}

While opioid analgesics can be used as the sole supplement to local and regional analgesia, they do not produce reliable sedation in the absence of considerable ventilatory depression. Therefore, opioid analgesics are commonly used in combination with sedative drugs to supplement the analgesia produced by local anaesthetics. Additional 
pain relief may be necessary during the initial injection of local anaesthetic solutions and to prevent discomfort from pressure and traction on deep tissues (and other structures) not rendered insensitive by the local anaesthetic solutions. Combinations of analgesic and sedativehypnotic drugs can enhance the degree of sedation and improve surgical conditions. For example, combinations of midazolam and alfentanil, or fentanyl and propofol, have been reported to provide highly satisfactory conditions for immersion shockwave lithotripsy. ${ }^{28}$. These sedative-analgesic regimens also provided for a shorter recovery period than an epidural-based technique.

While providing effective pain relief, opioid analgesics can also increase the incidence of undesirable perioperative side effects. In particular, opioids increase the incidence of postoperative nausea and vomiting, and can produce intraoperative respiratory depression when administered in the presence of sedative drugs. Fentanyl, $2.0 \mu \mathrm{g} \cdot \mathrm{kg}^{-1}$, produced transient hypoxaemia $\left(\mathrm{SpO}_{2}\right.$ $<90 \%$ ) in $50 \%$ of a group of healthy volunteers. ${ }^{7}$ The addition of midazolam, $0.05 \mathrm{mg} \cdot \mathrm{kg}^{-1}$, increased the incidence of transient desaturation to $92 \%$, and half of the subjects became apnoeic for at least $15 \mathrm{sec}$. In contrast, the same dose of midazolam produced no important respiratory effects when administered alone. It has been suggested that the synergistic interaction between opioid analgesics and benzodiazepines may have been responsible for a number of the fatalities reported during regional anaesthesia. ${ }^{29}$ Supplemental oxygen administration, combined with monitoring of respiratory function and haemoglobin oxygen saturation, is indicated when benzodiazepine-opioid combinations are administered. In contrast to midazolam, use of propofol may exacerbate opioid-induced respiratory depression to a lesser extent. The incidence of hypoxaemia with a propofol-fentanyl combination was half that observed with midazolam and alfentanil. ${ }^{28}$

Remifentanil is an investigational opioid analgesic which is metabolized by non-specific tissue esterases, resulting in an elimination half-life of 8-12 $\mathrm{min}$. Although remifentanil is capable of producing all of the usual opioid side effects, its short duration of action can reduce the clinical consequence of these undesirable effects. Preliminary studies suggest that an infusion of remifentanil, 0.1-0.15 $\mu \mathrm{g} \cdot \mathrm{kg}^{-1} \cdot \mathrm{min}^{-1}$, can provide satisfactory sedation and comfort during minor surgical procedures, while producing a useful degree of background analgesia. ${ }^{30}$ Further investigations are needed to determine whether remifentanil is superior to existing sedativehypnotic (e.g., midazolam, propofol) and analgesic (e.g., fentanyl, alfentanil) drugs, and to evaluate its interactions with these commonly-used sedative-hypnotic medications.
Non-steroidal antiinflammatory drugs (NSAIDs)

As a result of the adverse side effects associated with the currently available opioid analgesics, increasing interest has been focused on non-opioid analgesic drugs. ${ }^{31}$ Ketorolac is a potent, parenterally-active NSAID, which is becoming increasingly popular as a supplemental analgesic during local anaesthesia. The quality of intraoperative and postoperative analgesia was similar when ketorolac, $1 \mathrm{mg} \cdot \mathrm{kg}^{-1} \dot{i}$, was administered in place of fentanyl, $3 \mu \mathrm{g} \cdot \mathrm{kg}^{-1} \dot{\mathrm{n}}$, as the sole supplement to local anaesthesia during minor surgical procedures. ${ }^{32}$ More importantly, the incidence of pruritus, nausea and vomiting was much reduced by the use of ketorolac. Of interest, other investigators reported a very low incidence of nausea when smaller doses of opioid and non-opioid analgesics were used in combination with a propofol infusion during local anaesthesia. ${ }^{4}$ Although adjunctive use of ketorolac resulted in less postoperative sedation and a slightly earlier discharge than fentanyl, ketorolac-treated patients required higher doses of propofol for sedation, and were more likely to require supplemental intraoperative analgesia than patients receiving fentanyl.

\section{Alpha $_{2}$ agonists}

The alpha $a_{2}$ agonists, clonidine and dexmedetomidine, have considerable sedative, anxiolytic and analgesicsparing properties. In experimental animals, enhancement of the hypnotic effect of midazolam by clonidine is comparable to that produced by morphine, ${ }^{33}$ and it may prove to be a useful adjuvant during MAC. Furthermore, dexmedetomidine is a more highly selective and potent alpha agonist than clonidine. When administered prior to intravenous regional anaesthesia for hand surgery, dexmedetomidine decreased anxiety levels and reduced the requirements for supplemental analgesic medications compared with a control group. ${ }^{34}$ In fact, recovery from the sedative-anxiolytic effects of dexmedetomidine was reported to be superior to midazolam in outpatients undergoing minor gynaecological procedures. ${ }^{35}$ However, the use of dexmedetomidine has been associated with a high incidence of bradycardia, which may limit its clinical usefulness. ${ }^{34,36}$ Further investigations are required in order to define the place of alpha ${ }_{2}$ agonists in modern anaesthetic practice.

\section{Antagonist drugs}

The availability of the specific benzodiazepine antagonist, flumazenil, offers the possibility of decreasing the residual (postoperative) sedative and amnestic effects of midazolam, without a concomitant increase in the patient's level of anxiety. ${ }^{37}$ The administration of flumazenil, $1 \mathrm{mg} i v$, after minor surgery under local anaesthesia with midazolam sedation permitted discharge approximately $20 \mathrm{~min}$ 


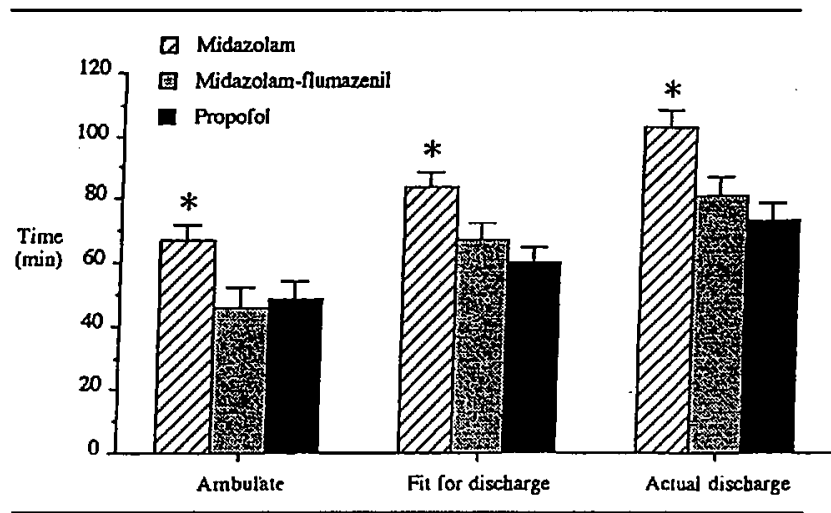

FIGURE 4 Recovery times following surgery with local anaesthesia and midazolam sedation (mean $10 \mathrm{mg}$ ) in patients receiving flumazenil, $1 \mathrm{mg}$ (solid bars), and a control group (open bars). Values represent means $\pm \mathrm{SEM}$. Adapted from Ghouri et al. ${ }^{38}$ with permission. ${ }^{*} P<$ 0.05 , from the control group.

earlier than a control group receiving a placebo flumazenil (Figure 4) ${ }^{38}$. Flumazenil also reduced the incidence and duration of postoperative amnesia without increasing recall of intraoperative events. This midazolamflumazenil combination was found to be similar to a propofol-based sedative regimen with respect to recovery times, as well as intraoperative and postoperative amnesia. ${ }^{38}$ However, flumazenil has a short duration of action (with an elimination half-life of 60-90 $\mathrm{min}$ ) which may result in "resedation" in the later recovery period. In contrast, once recovery from propofol sedation has occurred, resedation is extremely rare. While flumazenilassisted reversal of benzodiazepine-induced sedation (and amnesia) compares favourably with a propofol-based technique, it is unlikely that flumazenil will be used routinely for procedures performed under MAC. However, flumazenil might prove to be cost-effective in treating outpatients requiring large doses of benzodiazepines for brief diagnostic procedures (e.g., bronchoscopies), as well as for treating inadvertent episodes of excessive benzodiazepine-induced sedation.

\section{Use of combined sedative techniques}

Depending upon the needs of the individual patient and the specific operative procedure, there may be a requirement for varying degrees of amnesia, anxiolysis, sedation and analgesia during local and regional anaesthesia. Although propofol produces reliable, controllable sedation with a rapid recovery, it is relatively devoid of amnestic and analgesic properties. ${ }^{25}$ By contrast, midazolam is an excellent anxiolytic and amnestic agent, but is a less "titrable" hypnotic and has a slower recovery profile. By combining a small dose of midazolam with a continuous, low-dose propofol infusion, it is possible to combine the

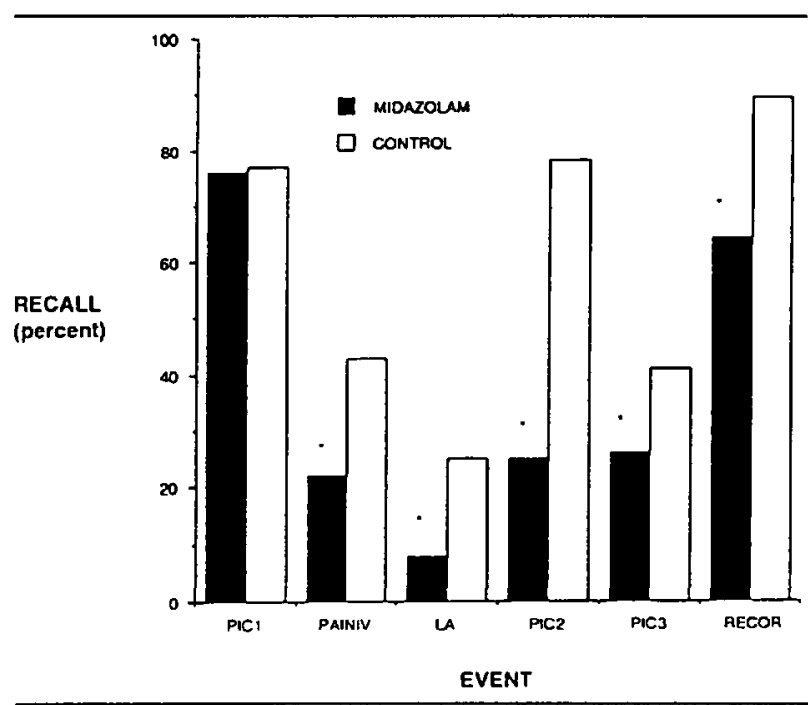

FIGURE 5 Recall of events during the perioperative period in patients receiving either midazolam $(2 \mathrm{mg}, i v)$ or saline $(2 \mathrm{ml})$ prior to sedation with a propofol infusion. Specific events included: (1) picture shown 3-5 min after the study drug, (2) pain on injection of propofol, (3) cutaneous injection of local anaesthetic solution, (4) picture shown at the time of the skin incision, (5) picture shown at the end of surgery, and (6) picture shown on arrival in the recovery room. Reproduced from Taylor $e t$ al. ${ }^{39}$ with permission. ${ }^{*} P<0.05$ from the saline (control) group.

beneficial effects of both agents without compromising recovery. ${ }^{39}$ In practice, preceding a variable-rate infusion of propofol with midazolam ( $2 \mathrm{mg} \dot{i})$, reduced patient anxiety, while increasing sedation scores and enhancing amnesia for intraoperative events compared with a control group receiving only the variable-rate propofol infusion (Figure 5) ${ }^{39}$ Furthermore, achievement of recovery endpoints was not delayed by the use of this midazolam and propofol "co-sedation" technique. Importantly, respiratory depression was not produced by the use of a small dose of midazolam, even when fentanyl was administered to provide supplemental analgesia during local anaesthetic injections. Other investigators have also reported upon the beneficial effects of using combinations of midazolam, propofol and opioids to enhance analgesia during painful procedures. ${ }^{28,40}$

\section{Patient-controlled sedation}

Marked individual variations in sensitivity to sedativehypnotic medications can make it difficult to provide the optimum degree of sedation for every patient during MAC. Furthermore, patients differ greatly in the degree of sedation that they desire during surgery, varying from complete wakefulness to "deep" sedation (approaching an hypnotic state) with complete amnesia. Finally, the level of stimulation and discomfort may change throughout 
the operative procedure, so that varying levels of sedation may be required at different times. One potential solution to this dilemma is to permit patients to self-administer their own sedative medications, titrating the sedative and/ or analgesic medication to their individual needs. The growing popularity of patient-controlled analgesia (PCA) has resulted in the availability of many types of infusion pump specifically designed for this purpose. During transvaginal ovum retrieval (a procedure characterized by intermittent painful stimuli), Zelcer $e t$ al. provided analgesia with alfentanil, administered either by the anaesthetist or by the PCA device. ${ }^{41}$ Identical doses of alfentanil were required by both groups of patients and similar pain scores and comfort levels were achieved during the procedure. Comparable haemodynamic and respiratory stability, perioperative side effects, and patient satisfaction were also achieved in both groups.

PCA infusion devices can also be used for patientcontrolled sedation (PCS). During epidural anaesthesia, patients who self-administered a midazolam-fentanyl mixture reported a higher degree of intraoperative comfort despite receiving similar doses of sedative medication to those in the control group. ${ }^{42}$ Propofol has also been administered using a PCS delivery system. A high level of patient satisfaction was reported when using a propofol bolus dose of $0.7 \mathrm{mg} \cdot \mathrm{kg}^{-1}$ and a lockout interval of three minutes during dental extractions, ${ }^{43}$ and in combination with regional anaesthesia. ${ }^{44}$ In comparison with anaesthetist-administered fentanyl-midazolam, patientadministered propofol resulted in greater patient satisfaction and improved postoperative cognitive function. ${ }^{45}$ However, these differences were probably more due to the use of propofol ( $v s$ midazolam) than to the use of PCS per se. Following premedication with midazolam, $2 \mathrm{mg}$, and fentanyl, $50 \mu \mathrm{g}$, the use of propofol, midazolam or alfentanil all produced a high level of patient satisfaction and similar recovery times when administered by a PCS technique during surgery under local anaesthesia. $^{46}$ However, propofol was associated with less postoperative nausea than was alfentanil, and midazolam produced more effective intraoperative amnesia and less pain on injection than propofol. The greater patient participation involved with PCS, combined with the inherent safety resulting from direct patient feedback, may lead to an increase in the use of patient-controlled sedation techniques in the future.

\section{Summary}

Local anaesthetic techniques are increasing in popularity because of the improved recovery profiles compared with general and regional anaesthesia (Table II). ${ }^{1,2,28,47,48}$ The use of intravenous adjuvants during local and regional anaesthesia can provide enhanced patient comfort while
TABLE II Techniques for administering local anaesthetics during monitored anaesthesia care (MAC) procedures

Peripheral nerve blocks

Ilioinguinal-iliohypogastric (e.g., herniorrhaphy)

Paracervical (e.g., D\&C, cone biopsy)

Dorsal penis (e.g., circumcision)

Peroneal/femoral/saphenous/tibial/sural (e.g., podiatric procedures)

Axillary/ulnar/media/radial (e.g., hand procedures)

Peribulbar/retrobulbar (e.g., ophthalmologic procedures)

Mandibular/maxillary (e.g., oral surgery)

Intravenous regional

Bier's block (e.g., arms, legs)

Tissue infiltration and wound instillation

Cosmetic and ENT procedures (e.g., blepharoplasty, nasal septum, endosinus)

Excision of masses and biopsies (e.g., breast, axilla, lipomas)

Field blocks or "splash" technique (e.g., hernia repair, vasovasotomy)

Laparoscopic procedures (e.g., cholecystectomy, tubal ligation)

Arthroscopic procedures (e.g., knees, shoulders)

Topical analgesia

Eutectic mixtures or local anaesthetics (EMLA) (e.g., lithotripsy, skin graphs)

Lidocaine spray (e.g., bronchoscopy, endoscopy, hernia repair)

Lidocaine gel or cream (e.g., circumcision, urological, oral surgery)

Cocaine paste (e.g., nasal, endosinus surgery)

optimizing intraoperative conditions. These sedativeanalgesic techniques may also be applied to procedures in which local anaesthetics are either unnecessary or impractical. While local anaesthetic-based regimens are generally perceived as safer than general anaesthesia, the addition of potent sedative-hypnotic and analgesic drugs may result in severe depression of central respiratory drive $^{7}$ and/or transient upper airway obstruction. ${ }^{17} \mathrm{Al}-$ though the use of carefully titrated infusions of rapid and short-acting sedative drugs should enhance patient safety, further studies are needed to determine the optimal delivery system for intravenous adjuvants. ${ }^{49}$ To achieve the desired results there is a need for vigilant monitoring, combined with supplemental oxygen administration and the availability of resuscitation equipment. Concerns regarding the increasing cost of health care has necessitated a careful examination of the cost-benefit of all newer sedative-analgesic drugs and techniques. Recently, Kain et al. ${ }^{50}$ reported that propofol was actually more costeffective than inexpensive barbiturate drugs when used for sedation outside the operating room because of its more favourable recovery profile.

In conclusion, the availability of newer sedative and analgesic drugs with more specific actions, shorter durations of action and reduced side effects, as well as newer techniques like PCS, should improve patient safety and comfort during local and regional anaesthesia in the future. 


\section{References}

1 White PF, Negus JB. Sedative infusions during local and regional anesthesia: a comparison of midazolam and propofol. J Clin Anesth 1991; 3: 32-9.

2 Raeder JC. Propofol anaesthesia versus paracervical blockade with alfentanil and midazolam sedation for outpatient abortion. Acta Anaesthesiol Scand 1992; 36: 31-7.

3 Brown $A R$, Weiss $R$, Greenberg $C$, Flatow EL, Bigliani $L U$. Interscalene block for shoulder arthroscopy: comparison with general anesthesia. Arthroscopy 1993; 9: 295-300.

4 Ramirez-Ruiz $M$, Newson CD, White PF. Monitored anesthesia care: use of ketorolac, dezocine and fentanyl. Anesthesiology 1992; 77: A27.

5 Tucker $M R$, Ochs $M W$, White RP Jr. Arterial blood gas levels after midazolam or diazepam administered with or without fentanyl as an intravenous sedative for outpatient surgical procedures. J Oral Maxillofac Surg 1986; 44 : 688-92.

6 White CS, Dolwick MF, Grovenstein N, Paulus DA. Incidence of oxygen desaturation during oral surgery outpatient procedures. J Oral Maxillofac Surg 1989; 47: 147-50.

7 Bailey PL, Pace NL, Ashburn MA, Moll JWB, East KA, Stanley $T H$. Frequent hypoxemia and apnea after sedation with midazolam and fentanyl. Anesthesiology 1990; 73: 826-30.

8 Korttila $K$, Linnoila $M$. Recovery and skills related to driving after intravenous sedation: dose-response relationship with diazepam. Br J Anaesth 1975; 47: 457-63.

9 Gale GD. Recovery from methohexitone, halothane and diazepam. Br J Anaesth 1976; 48: 691-8.

10 White PF, Vasconez LO, Mathes SA, Way WL, Wender $L A$. Comparison of midazolam and diazepam for sedation during plastic surgery. Plast Reconstr Surg 1988; 81: 703-10.

11 McClure JH, Brown DT, Wildsmith JAW. Comparison of the I.V. administration of midazolam and diazepam as sedation during spinal anaesthesia. Br J Anaesth 1983; 55 : 1089-93.

12 White PF, Way WL, Trevor AJ. Ketamine - its pharmacology and therapeutic uses. Anesthesiology 1982; 56: 119-36.

13 Coppel DL, Bovill JG, Dundee JW. The taming of ketamine. Anaesthesia 1973; 28: 293-6.

14 Lilburn JK, Dundee JW, Nair SG, Fee JPH, Johnston $H M L$. Ketamine sequelae. Evaluation of the ability of various premedicants to attenuate its psychic actions. Anaesthesia 1978; 33: 307-11.

15 White PF. Comparative evaluation of intravenous agents for rapid sequence induction - thiopental, ketamine and midazolam. Anesthesiology 1982; 57: 279-84.

16 Monk TG, Rater $J M$, White $P F$. Comparison of alfentanil and ketamine infusions in combination with midazolam for outpatient lithotripsy. Anesthesiology 1991; 74: 1023-8.
17 Urquhart $M L$, White PF. Comparison of sedative infusions during regional anesthesia - methohexital, etomidate and midazolam. Anesth Analg 1989; 68: 249-54.

18 Mackenzie N, Grant IS. Propofol for intravenous sedation. Anaesthesia 1987; 42: 3-6.

19 Wilson E, Mackenzie N, Grant IS. A comparison of propofol and midazolam by infusion to provide sedation in patients who receive spinal anaesthesia. Anaesthesia 1988; 43(Supplement): 91-4.

20 Pratila $M G$, Fischer ME, Alagesan $R$, Alagesan $R$, Reinsel $R A$, Pratilas $D$. Propofol versus midazolam for monitored sedation: a comparison of intraoperative and recovery parameters. J Clin Anesth 1993; 5: 268-74.

21 Valtonen $M$, Salonen $M$, Forssell $H$, Scheinin $M$, Viinamäki $O$. Propofol infusion for sedation in outpatient oral surgery. A comparison with diazepam. Anaesthesia 1989; 44: 730-4.

22 Ferrari $L R$, Donlon JV. A comparison of propofol, midazolam, and methohexital for sedation during retrobulbar and peribulbar block. J Clin Anesth 1992; 4: 93-6.

23 Dubois A, Balatoni E, Peeters JP, Baudoux M. Use of propofol for sedation during gastrointestinal endoscopies. Anaesthesia 1988; 43: 75-80.

24 Patterson KW, Casey PB, Murray JP, O'Boyle CA, Cunningham $A J$. Propofol sedation for outpatient upper gastrointestinal endoscopy: comparison with midazolam. $\mathrm{Br}$ J Anaesth 1991; 67: 108-11.

25 Smith, White PF, Nathanson $M$, Gouldson $R$. Propofol: an update on its clinical uses. Anesthesiology 1994; 81: 1005-43.

26 Rosa $G$, Conti $G$, Orsi $P$, et al. Effects of low-dose propofol administration on central respiratory drive, gas exchanges and respiratory pattern. Acta Anaesthesiol Scand 1992; 36: 128-31.

27 Smith I, Monk TG, White PF, Ding Y. Propofol infusion during regional anesthesia: Sedative, amnestic and anxiolytic properties. Anesth Analg 1994; 79: 313-9.

28 Monk TG, Bouré B, White PF, Meretyk S, Clayman RV. Comparison of intravenous sedative-analgesic techniques for outpatient immersion lithotripsy. Anesth Analg 1991; 72: 616-21.

29 Caplan RA, Ward RJ, Posmerk, Cheney FW. Unexpected cardiac arrest during spinal anesthesia: a closed claims analysis of predisposing factors. Anesthesiology 1988; 68: 5-11.

30 Avramov $M$, Smith I, White $P F$. Use of midazolam and remifentanil during monitored anesthesia care (MAC). Anesth Analg 1995; 80: S24.

31 Souter A, Fredman B, White PF. Controversies in the perioperative use of non-steroidal antiinflammatory drugs. Anesth Analg 1994; 79: 1178-90.

32 Bosek V, Smith $D B$, Cox C. Ketorolac or fentanyl to supplement local anesthesia? J Clin Anesth 1992; 4: 480-3. 
33 Kissin I, Brown PT, Bradley EL. Additive clonidinemorphine interaction for enhancement of midazolam hypnotic effect. Anesthesiology 1992; 77: A725.

34 Jaakola $M-L$, Scheinin H, Scheinin M, Kallio $A$. Dexmedetomidine premedication before regional intravenous anesthesia in minor outpatient hand surgery. Anesthesiology 1992; 77: A836.

35 Aho $M$, Erkola $Q$, Kallio A, Scheinin H, Kontila $K$. Comparison of dexmedetomidine and midazolam sedation and antagonism of dexmedetomidine with atipamezole. J Clin Anesth 1993; 5: 194-203.

36 Aho MS, Erkola OA, Scheinin H, Lehtinen A-M, Korttila $K T$. Effect of intravenously administered dexmedetomidine on pain after laparoscopic tubal ligation. Anesth Analg 1991; 73: 112-8.

37 White PF, Shafer A, Boyle WA, Doze VA, Duncan S. Benzodiazepine antagonism does not provoke a stress response. Anesthesiology 1989; 70: 636-9.

38 Ghouri AF, Ramirez Ruiz MA, White PF. Effect of flumazenil on recovery after midazolam and propofol sedation. Anesthesiology 1994; 81: 333-9.

39 Taylor E, Ghouri AF, White PF. Midazolam in combination with propofol for sedation during local anesthesia. J Clin Anesth 1992; 4: 213-6.

40 Sherry $E$. Admixture of propofol and alfentanil. Use for intravenous sedation and analgesia during transvaginal oocyte retrival. Anaesthesia 1992; 47: 477-9.

41 Zelcer J, White PF, Chester S, Paull JD, Molnar R. Intraoperative patient-controlled analgesia: an alternative to physician administration during outpatient monitored anesthesia care. Anesth Analg 1992; 75: 41-4.

42 Park WY, Watkins PA. Patient-controlled sedation during epidural anesthesia. Anesth Analg 1991; 72: 304-7.

43 Rudkin GE, Osborne GA, Curtis NJ. Intraoperative patient-controlled sedation. Anaesthesia 1991; 46: 90-2.

44 Grattidge P. Patient-controlled sedation using propofol in day-surgery. Anaesthesia 1992; 47: 683-5.

45 Osborne GA, Rudkin GE, Curtis NJ, Vickers D, Craker $A J$. Intra-operative patient-controlled sedation. Comparson of patient-controlled propofol with anaesthetistadministered midazolam and fentanyl. Anaesthesia 1991; 46: 553-6.

46 Ghouri AF, Taylor E, White PF. Patient-controlled drug administration during local anesthesia: a comparison of midazolam, propofol, and alfentanil. J Clin Anesth 1992; 4: 476-9.

47 Tverskoy M, Cozacov C, Ayache M, Bradley EL, Kissin I. Postoperative pain after inguinal herniorrhaphy with different types of anesthesia. Anesth Analg 1990; 70: 29-35.

48 Ding $Y$, White $P F$. Post-herniorrhaphy pain in outpatients after pre-incision ilioinguinal-hypogastric nerve block during monitored anaesthesia care. Can J Anaesth 1995; 42 : $12-5$.
49 Newson C, Victory $R$, Joshi G, Ostman P, White PF. Propofol sedation: use of infusion pumps vs manual administration. Anesthesiology 1993; 79: A3.

50 Kain ZV, Gaal DJ, Kain TS, Jaeger DD, Rimar $S$. A first-pass cost analysis of propofol versus barbiturates for children undergoing magnetic resonance imaging. Anesth Analg 1994; 79: 1102-6. 
Paul F. White, Ian Smith

\section{La sédation pendant l'anesthésie locorégionale}

L'accès à de meilleurs sédatifs et à de nouvelles techniques permet de réaliser une plus grande variété d'interventions chirurgicales sous anesthésie locale et régionale (Tableau I). L'infiltration locale du champ operatoire, l'anesthésie régionale $\dot{i}$, les blocs nerveux périphériques et les blocs centraux (c.-à-d. l'anesthésie rachidienne et épidurale) figurent parmi les techniques les plus populaires. Parmi les avantages des techniques qui font appel aux anesthésiques locaux, il faut mentionner la sauvegarde des réflexes protecteurs des voies aériennes, l'analgésie postopératoire résiduelle et l'absence des effets secondaires associés à l'anesthésie générale (par ex., la dépression respiratoire et cardiovasculaire, les nausées, les vomissements, la confusion et les étourdissements). Les blocs nerveux périphériques ou l'infiltration locale associés aux sédatifs i $v$ (midazolam, propofol) améliorent la qualité du réveil en minimisant la douleur postopératoire et les vomissements comparativement aux techniques anesthésiques régionales centrales et à l'anesthésie générale. ${ }^{1-3}$

Les interventions chirurgicales réalisées sous anesthésie locale peuvent incommoder le patient pour plusieurs raisons. D'abord, l'injection sous-cutanée d'un anesthésique local est souvent douloureuse, surtout si elle est répétée plusieurs fois (par ex., en chirurgie cosmétique); deuxièmement, les tractions sur les structures profondes et la nécessité de demeurer immobile pendant de longues périodes sur une table d'opération étroite et dure incommodent en général le patient; finalement, plusieurs patients trouvent pendant la chirurgie très angoissants l'environnement de la salle d'opération et la perspective d'y être conscients. Pour ces raisons, les techniques anesthésiques locorégionales sont souvent combinées à des médications d'appoint qui procurent l'amnésie, la sédation et l'analgésie et, de plus, diminuent l'anxiété. Des sédatifs et les analgesiques sont adjoints à l'anesthésie locale pour donner un plus grand confort pendant des interventions diagnostiques et therapeutiques douloureuses (par ex., l'endoscopie, la radiothérapie, l'imagerie, la lithotritie). Les situations au cours desquelles des agents anesthésiques ou d'appoint sont administrés par un anesthésiste avec ou sans infiltration pourraient rassemblées sous l'expression " gestion anesthésique monitorée "(GAM) (Tableau II).
Le degré de sédation peropératoire doit être adapté aux besoins de lindividu et subit linfluence du type d'intervention projetée. De plus, l'anxiété du patient peut être grandement réduite si on lui communique des renseignements complets sur l'intervention anticipée, si on converse avec lui pendant lintervention, si les stimuli auditifs et visuels sont réduits au minimum dans la salle d'opération et si on maintient le patient bien couvert et à la chaleur tout au long de lintervention. La douleur de lincision devrait être allégée par une infiltration locale ou un bloc du champ opératoire. Toutefois, il est souvent nécessaire de faire appel à des analgésiques morphiniques ou d'autres types associés à des sédatifs et de les adjoindre à l'anesthésie locale dans le but d'interrompre les sensations douloureuses survenant à distance du site opératoire. ${ }^{4} \mathrm{La}$ sédation et la confort du patient ne doivent pas compromettre sa sécurité. La sédation excessive peut interdire toute communication et laisser les voies aériennes sans protection et, par conséquent, aggraver le risque de complications associé à l'aspiration. Quand des médications d'appoint sont administrées, un supplément d'oxygène est fortement recommandé pour prévenir la désaturation en oxygène par dépression de l'effort respiratoire ou par obstruction des voies aériennes supérieures. ${ }^{5-7}$ Les moniteurs habituels et l'équipement de réanimation doivent être, de toute évidence, accessibles instantanément.

\section{Choix des sédatifs}

Parmi les agents d'appoint dont nous disposons pour l'optimisation des conditions opératoires tant pour le patient que pour le chirurgien, il faut mentionner les benzodiazépines, les morphiniques et anti-inflammatoires non stéroïdiens (AINS), et, en plus, les anesthésiques en doses sous-anesthésiques (par ex., les barbituriques, l'étomidate, le propofol et la kétamine). Les voies d'administration varient (par ex., transmuqueuse, parentérale ou inhalatoire) et s'adaptent aux patients opérés sous anesthésie locale ou régionale. La voie orale est restreinte parce qu'elle retarde le début des effets cliniques et n'offre pas de contrôle suffisamment précis du niveau de sédation. Alors que l'anesthésie par inhalation évite plusieurs de ces problèmes, l'âcreté de l'odeur des agents présentement en usage et leur propension à accentuer les nausées et vomissements postopératoires les rendent inacceptables à 
TABLEAU I Interventions réalisables sous anesthésie loco-régionale
Interventions sous sédation avec ou sans anesthésie topique

Interventions sous sédation avec infiltration locale d'anesthésique (ou blocs)

Intervention sous sédation et anesthésie régionale
Endoscopie du tractus digestif supérieur Bronchoscopie flexible

Lithotritie extracorporelle par ondes de choc

Récupération transvaginale d'ovule et autres interventions vaginales

Radiothérapie et imagerie par résonance magnétique en pédiatrie

Angiographie, installation de pacemaker, cathéter intravasculaire, installation d'un filtre veineux

Chirurgie dentaire (extraction et conservation)

Cataracte et autre chirurgie oculaire

Excision de tumeurs et lésions corporelles

Chirurgie et polypectomie des sinus

Arthroscopie, décompression de tunnel carpien, interventions orthopédiques mineures

Circoncision, herniorraphie, varicectomie Septorhinoplastie, chirurgie cosmétique

Vasectomie et orchidopexie

D \& C et chirurgie du périné

Cystoscopie, resection transurethrale de tumeurs et de la prostate

Arthroscopie et intervention orthopédiques périphériques

D \& C, hystérectomie ef réparations vaginales, chirurgie du périnée

Herniorraphie, hémorroĩdectomie bien des patients. De plus, même à concentrations infimes, les agents inhalatoires polluent l'environnement des salles d'opérations et comportent des risques pour le personnel médical et auxiliaire. Quoique l'administration transmuqueuse pourrait à l'avenir gagner en popularité (il faut noter l'approbation récente par la FDA du système d'administration de fentanyl Oralette), la voie intraveineuse continue d'être l'approche la plus populaire présentement. La connaissance des propriétés pharmacologiques et physiologiques des sédatifs-hypnotiques, des anxiolytiques et analgésiques utilisés couramment est essentielle à la réalisation de conditions chirurgicales optimales et à des résultats acceptables quand on utilise des techniques de sédation. Comme des médications anesthésiques et analgésiques faisant partie de deux ou de plusieurs groupes de drogues sont souvent combinées, il faut aussi tenir compte des interactions possibles.

\section{Les sédatifs-hypnotiques}

\section{Les benzodiazépines}

Toutes les benzodiazépines sont capables de produire
TABLEAU II Techniques utilisant des anesthésiques locaux pendant la gestion anesthésique monitorée (GAM)

Blocs nerveux périphériques

Ilioinguinal, iliohypogastrique (par ex., herniorraphie)

Paracervical (par ex., D \& C, conisation cervicale)

Dorsal du pénis (par ex., circoncision)

Péroné, fémoral, saphène, tibial, sural (par ex, en chirurgie pédiatrique)

Axillaire, cubital, médian, radial (par ex., interventions sur la main)

Péribulbaire, rétrobulbaire (par ex., interventions oculaires)

Mandibulaire, maxillaire (par ex., chirurgie orale)

Anesthésie régionale intraveinetuse

Bloc de Bier (par ex., membres sup. et inf.)

Infiltration des tissus ou instillation de plaie

Chirurgie cosmétique et ORL (par ex., blépharoplastie, septum nasal, sinus)

Excision de masses et biopsies (par ex., sein, aiselle, lipômes)

Blocs du champ opératoire ou barbotage (par ex., réparation de hernie)

Interventions laparascopiques (par ex., cholécystectomie, ligature tubaire)

Interventions arthroscopiques (par ex., genou, épaule)

\section{Anesthésie topique}

Mélange eutectique (EMLA) (par ex., lithotripsie, greffes cutanés)

Aérosol de lidocaine (par ex., bronchoscopie, endoscopie, réparation de hernie)

Gel ou crême de lidocaîne (par ex., circoncision, urologie, chirurgie buccale)

Pâte de cocaïne (par ex., nez, chirurgie endosinusale)

l'anxiolyse ainsi que l'amnésie et la sédation. La dépression du système nerveux central (SNC) induite par les benzodiazépines est proportionnelle à la posologie et peut varier de la sédation légère à l'hypnose (l'inconscience). Le prototype des benzodiazépines, le diazépam, possède une longue demi-vie d'élimination (24-48 h), ce qui peut retarder le réveil et provoquer une sensation d'obnubilation (hangover) après la chirurgie. Par ex., une dose de diazépam de 0,2 à $0,4 \mathrm{mg} \cdot \mathrm{kg}^{-1}$ iv compromet la capacité de conduire une voiture pendant dix heures et prolonge la période de réveil encore plus que l'anesthésie générale. ${ }^{8,9}$ Les effets du diazépam peuvent se prolonger chez les personnes âgées, secteur de la population pour lequel les techniques d'anesthésie locorégionale sont très souvent préférées. Le retour à la sédation causé par l'hydrolyse en métabolites actifs et la recirculation entérohépatique est toujours possible. Cette reprise de la sédation est particulièrement inquiétante en chirurgie ambulatoire parce qu'elle peut se produire après le retour du patient à son domicile. Finalement, le diazépam est insoluble dans l'eau et a besoin d'un solvant organique comme le propylène glycol pour former une solution stable propre à l'administration intraveineuse. Ces solvants produisent de l'irritation veineuse et favorisent la forma- 
tion de phlébites; ces effets diminuent avec la préparation de diazépam en émulsion (Diazemuls).

A cause de sa solubilité aqueuse et parce qu'il n'entraîne pas de douleur à linjection et nirrite pas les veines, le midazolam constitue une benzodiazépine plus acceptable. ${ }^{10}$ Le midazolam agit plus rapidement, a une demivie d'élimination plus courte $(2-4 \mathrm{~h})$, ne possède pas de métabolites actifs ni n'emprunte la circulation entérohépatique; ces caractéristiques permettent une récupération plus rapide après une intervention de courte durée. Comparé à celle du diazépam, la pente de la relation doseeffet du midazolam est plus aiguë (Figure 1), ce qui nécessite un titrage iv plus précis pour atteindre l'effet désiré tout en évitant une surdose accidentelle. ${ }^{10}$ Les conséquences de l'âge et de la condition physique préopératoire exagérent la sensibilité au midazolam et la variabilité des effets entre individus. La plupart des études accordent au midazolam un début d'action plus rapide que celui du diazépam. L'amnésie, l'anxiolyse et la sédation périopératoires qu'il procure sont plus importantes. ${ }^{10}$ Quoique avec le midazolam, le réveil complet survienne rapidement, les doses trop généreuses de midazolam $(0,2$ $\mathrm{mg} \cdot \mathrm{kg}^{-1}$ ) peuvent causer une sédation postopératoire très prolongée."

\section{La kétamine}

La kétamine est un dérivé de la phencyclidine qui produit des états sédatifs et anesthésiques soi-disant " dissociatifs $"{ }^{12}$ Bien que des doses sous-hypnotiques de kétamine puissent donner un degré de sédation et d'amnésie efficaces pendant l'anesthésie locorégionale, c'est la caractéristique analgésiante de la kétamine qui présente, pour le patient, le bénéfice le plus important. La kétamine $0,25-0,75 \mathrm{mg} \cdot \mathrm{kg}^{-1}$ iv procure au patient un confort appréciable pendant les injections de grands volumes d'un anesthésique local en solution étendue comme on en utilise en chirurgie plastique. ${ }^{10} \mathrm{De}$ plus, la kétamine peut fournir une anesthésie supplémentaire au cours d'un bloc médullaire incomplet. L'analgésie produite par des petites doses de kétamine ne s'accompagne ordinairement pas de dépression respiratoire importante.

Lorsqu'on utilise la kétamine seule, on doit faire face à une incidence élevée de phénomènes d'émergence et à d'autres effets secondaires à l'excitation. ${ }^{13}$ Cependant, on peut minimiser ces effets indésirables en adjoignant à la kétamine une benzodiazépine ou un autre sédatifhypnotique. ${ }^{14}$ En plus d'accroître la sédation et l'amnésie, les benzodiazépines atténuent les effets cardiostimulateurs de la kétamine et procurent ainsi une stabilité cardiovasculaire remarquable. ${ }^{15}$ Après l'administration de midazolam, une perfusion de kétamine $25 \mu \mathrm{g} \cdot \mathrm{kg}^{-1} \cdot \mathrm{min}^{-1}$ produit la sédation et une analgésie efficaces pendant la lithotritie extracorporelle par ondes de choc. ${ }^{16}$ Cependant,

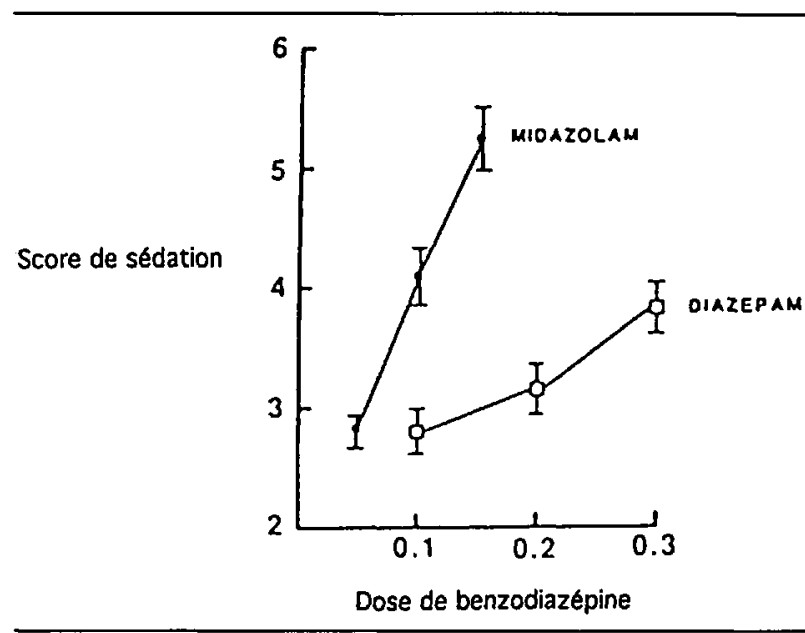

FIGURE 1 Relation entre le score de sédation ( 2 = éveille/relax à 6 $=$ endormi/aréactif) et la dose de midazolam ou de diazepam. Les valeurs représentent une moyenne \pm SEM. Reproduit avec la permission de White et al. ${ }^{10}$

l'incidence élevée de mouvements incoordonnés et d'effets secondaires qui surviennent à la période postopératoire immédiate (par ex., l'agitation, les cauchemars, la confusion) restreignent son utilité pour cette intervention. De plus, la récupération et le congé postopératoires peuvent être considérablement retardés après une chirurgie ambulatoire courte comparativement aux autres modes de sédation. Comme initialement avec l'association kétamine-thiopentone, ${ }^{15}$ l'association kétamine-propofol gagne présentement en popularité.

\section{Le propofol}

Les anesthésiques intraveineux comme le propofol peuvent être utilisés en doses sous-hypnotiques pour produire différents degrés de sédation. ${ }^{17}$ Typiquement, on utilise des perfusions de thiopentone $3-9 \mathrm{mg} \cdot \mathrm{min}^{-1}$, de méthohexital 1-3 $\mathrm{mg} \cdot \mathrm{min}^{-1}$, de midazolam 0,06-0,18 $\mathrm{mg} \cdot \mathrm{min}^{-1}$, d'étomidate $0,2-0,6 \mathrm{mg} \cdot \mathrm{min}^{-1}$, et propofol $2-5 \mathrm{mg} \cdot \mathrm{min}^{-1}$. Cependant, l'utilisation de dépresseurs de SNC à longue durée d'action peut mener à un piètre contrôle du niveau d'hypnose et à un retard du réveil par persistance des effets sédatifs. Au contraire, la redistribution rapide et la courte demi-vie d'élimination du propofol permet au patient de récupérer rapidement des effets hypnotiques aussi bien après une seule dose en bolus qu'après une perfusion continue. Le bref délai d'action du propofol entraîne une réponse rapide aux changements de vitesse de la perfusion, avec un titrage optimal et une grande facilité de maniement.

En 1987, MacKenzie et Grant ont administré du propofol en perfusion à la vitesse de $3,8 \mathrm{mg} \cdot \mathrm{kg}^{-1} \cdot \mathrm{h}^{-1}$ à des malades soumis à une intervention aux membres inférieurs sous anesthésie rachidienne. ${ }^{18} \mathrm{~A}$ cette dose re- 
lativement élevée, en variant la vitesse de la perfusion, les patients dorment mais se réveillent sur commande verbale et sont facilement maintenus sous sédation. En moins de quatre minutes après l'arrêt de la perfusion, ils s'éveillent et se disent en pleine possession de leurs facultés. Les auteurs mentionnent la facilité avec laquelle ils passent à l'anesthésie générale si la chirurgie devenaient plus extensive que prévu. Dans une étude de suivi, ces auteurs comparent la même vitesse de perfusion du propofol avec une perfusion de midazolam $\left(0,27 \mathrm{mg} \cdot \mathrm{kg}^{-1} \cdot \mathrm{h}^{-1}\right)$ utilisée comme complément à l'anesthésie rachidienne. ${ }^{19}$ Ils obtiennent une sédation comparable pour les deux produits; cependant, les patients sous propofol s'éveillent en moins de deux minutes comparativement à neuf minutes pour ceux qui ont reçu du midazolam. Finalement, White et Negus ont montré qu'une perfusion de propofol est plus facile à titrer pour la sédation comparativement à la perfusion de midazolam pendant une chirurgie réalisée sous anesthésie locorégionale. ' Comparativement au midazolam, l'administration de propofol réduit l'incidence de l'excès de sédation, ce qui permet de minimiser la sédation postopératoire indésirée, la somnolence, la confusion, la sensation de lourdeur et l'amnésie (Figure 2). Comparativement au propofol, le midazolam est associé à une altération considérable de la fonction cognitive jusqu’à une période aussi prolongée que trois heures après lintervention.

Les perfusions de propofol à doses faibles sont aussi utilisées comme compléments aux infiltrations locales chez des patients programmés pour des installations d'accès veineux centraux, ${ }^{20}$ pour la chirurgie orale, ${ }^{21}$ et pour des interventions chinurgicales superficielles, dont des biopsies du sein et des herniorraphies. ${ }^{1,4}$ Avec le propofol, la récupération immédiate et intermédiaire est supérieure à celle que produit le midazolam et le diazépam. ${ }^{21}$ Ferrario et Donlon ont comparé des injections en bolus de propofol $0,5 \mathrm{mg} \cdot \mathrm{kg}^{-1}$ avec le midazolam $0,02 \mathrm{mg} \cdot \mathrm{kg}^{-1}$ et le méthohexitone $0,45 \mathrm{mg} \cdot \mathrm{kg}^{-1}$ pour la sédation pendant des blocs rétrobulbaires et péribulbaires réalisés pour des interventions ophtalmiques. ${ }^{22}$ Les patients qui reçoivent du propofol se rappellent moins souvent de l'exécution du bloc local et profitent d'une meilleur sédation pendant la suite de lintervention. Le propofol est particulièrement bénéfique en chirurgie ophtalmologique à cause de ses propriétés sédatives, sa capacité de réduire la pression intraoculaire et de prévenir les nausées. La sédation au propofol produit aussi des conditions satisfaisantes pour les manoeuvres endoscopiques effectuées sur le tractus digestif supérieur. ${ }^{23}$ Pour ce type dintervention diagnostique, des conditions très acceptables accompagnées d'une bonne amnésie et d'un réveil rapide sont possible avec une perfusion de propofol $4,3 \mathrm{mg} \cdot \mathrm{kg}^{-1} \cdot \mathrm{h}^{-1}$. Patterson et al. rapportent une récu-
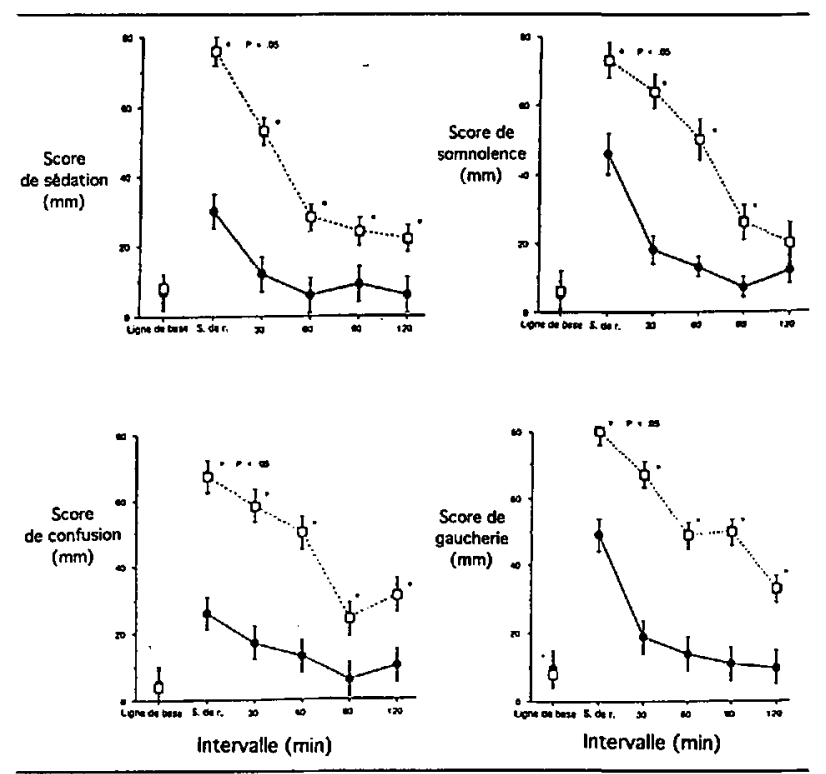

FIGURE 2 Score périopératoire sur EVA (échelle visuelle analogique) de sédation, somnolence, confusion et maladresse des patients qui reçoivent soit du midazolam (carrés vides) ou du propofol (cercles pleins) pendant une chirurgie sous anesthésie locale. Les valeurs représentent la médiane \pm SEM. Reproduit avec la permission de White et Negus. ${ }^{1} * P<0,05$ comparativement au groupe propofol.

pération plus rapide et une réduction plus importante de l'obnubilation avec le propofol qu'avec le midazolam, quand ces agents sont administrés pour des manoeuvres endoscopiques sur le tractus digestif supérieur. ${ }^{23}$

Comme sédatif, le propofol semble associé à une faible incidence d'effets secondaires indésirables. ${ }^{25} \mathrm{Le}$ propofol provoque rarement des phénomènes d'excitation et des mouvements incontrôlables et peu de nausées et de vomissements postopératoires. Il est important de noter qu'à faible dose, la perfusion de propofol déprime très peu le système cardiovasculaire et le système respiratoire. ${ }^{26}$ Plusieurs chercheurs mentionnent que l'amnésie procurée par le propofol à dose sous-hypnotiques est légère comparativement aux benzodiazépine. ${ }^{1,19,20,27}$ Smith et al. ont administré quatre différentes mélanges bolus-perfusion pour des interventions urologiques sous anesthésie régionale. ${ }^{27}$ La sédation augmente progressivement avec des perfusions de propofol de $0,5,1,2$ et $4 \mathrm{mg} \cdot \mathrm{kg}^{-1} \cdot \mathrm{h}^{-1}$ (Figure 3). L'amnésie (dans ce cas, l'incapacité d'identifier une image déjà vue) pendant et immédiatement après l'intervention n'est pas manifeste pour les deux premiers groupes. Cependant pour les deux autre groupes qui reçoivent la dose la plus importante, seulement $65 \%$ et $18 \%$ se souviennent de faits survenus pendant lintervention. En outre, la faible incidence d'amnésie postopératoire obtenue avec le propofol (vs midazolam) constitue une caractéristique avantageuse après une chirurgie ambulatoire. 

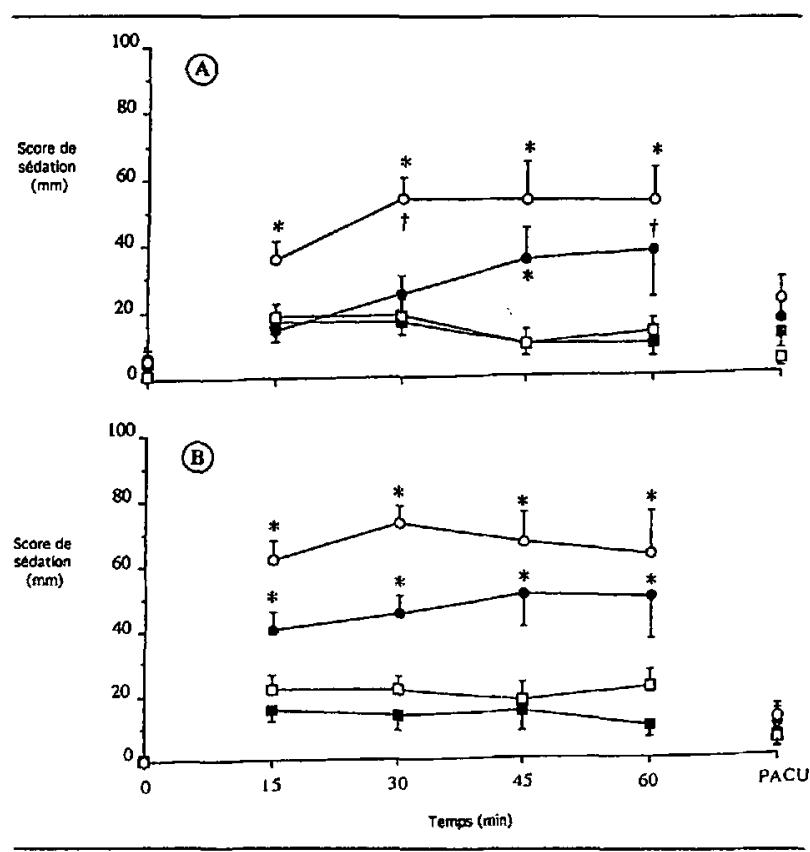

FIGURE 3 Les scores sur EVA transmis par les patients (A) et par un observateur neutre (B) avant (temps), pendant et après (salle de réveil) sédation au propofol. Les patients ont reçu propofol, 0,2 $\mathrm{mg} \cdot \mathrm{kg}^{-1}$ et $0,5 \mathrm{mg} \cdot \mathrm{kg}^{-1} \cdot \mathrm{h}^{-1}$ (Groupe l; carrés pleins); 0,4 $\mathrm{mg} \cdot \mathrm{kg}^{-1}$ et $\mathrm{l} \mathrm{mg} \cdot \mathrm{kg}^{-1} \cdot \mathrm{h}^{-1}$ (Groupe 2: carrés vides); 0,5 $\mathrm{mg} \cdot \mathrm{kg}^{-1} \cdot \mathrm{h}^{-1}$ (Groupe 3; cercles pleins); et $0,7 \mathrm{mg} \cdot \mathrm{kg}^{-1}$ et 4 $\mathrm{mg} \cdot \mathrm{kg}^{-1} \cdot \mathrm{h}^{-1}$ (Groupe 4; cercles vides). Les valeurs représentent la moyenne \pm SEM. Reproduit avec la permission de Smith et al. ${ }^{27} * P$ $<0,05$, comparaison avec groupe $\mathrm{l} ; \uparrow P<0,05$, valeur à $15 \mathrm{~min}$ pour le même groupe.

\section{Les adjuvants de l'analgésie}

\section{L'analgésie aux opiacés}

Quoique les analgésiques opiacés puissent être utilisé isolément en supplément à l'anesthésie locorégionale, ils ne produisent pas de sédation constante, si ce n'est avec une dépression respiratoire considérable. C'est la raison pour laquelle les morphiniques sont ordinairement utilisés en association avec des sédatifs pour procurer un supplément d'analgésie à celle que produisent les anesthésiques locaux. Un soulagement additionnel peut devenir nécessaire au début de l'injection d'une solution d'anesthésique local et pour prévenir le malaise généré par la pression et les tractions exercées sur les plans tissulaires profonds (ou autres structures) qui ne sont pas insensibilisés par l'anesthésie locale. Les associations de sédatifs-hypnotiques avec des analgésiques augmentent le niveau de sédation et améliorent les conditions opératoires. Par exemple, l'assocation midazolam-alfentanil et propofol-fentanyl procurent des conditions très satisfaisantes pour la lithotritie extracorporelle par ondes de choc. ${ }^{28}$ Avec ces mélanges, la phase de récupération est plus courte qu'avec une anesthésie épidurale.
Tout en soulageant la douleur efficacement, les morphiniques augmentent aussi quelquefois lincidence des effets indésirables périopératoires. Les morphiniques, en particulier, accroissent l'incidence des nausée et vomissements postopératoires et provoquent de la dépression respiratoire peropératoire lorsqu'on les administre avec des sédatifs. Le fentanyl, $2,0 \mu \mathrm{g} \cdot \mathrm{kg}^{-1}$, provoque de l'hypoxémie passagère $\left(\mathrm{SPO}_{2}<90 \%\right)$ chez $50 \%$ des membres d'un groupe de volontaires. ${ }^{7}$ L'ajout de midazolam, $0,05 \mathrm{mg} \cdot \mathrm{kg}^{-1}$, fait passer l'incidence de cette désaturation transitoire à $92 \%$ et la moitié des sujets manifestent une période d'apnée d'au moins $15 \mathrm{sec}$. A l'opposé, la même dose de midazolam seule ne produit pas d'effets respiratoires significatifs. On a même suggéré que linteraction synergique des morphiniques avec les benzodiazépines pourrait avoir été responsable de certains décès survenus sous anesthésie régionale. ${ }^{29}$ L'ajout d'oxygène avec monitorage de la fonction respiratoire et de la saturation est nettement indiqué quand des associations de morphiniques et de benzodiazépines sont administrées. Lorqu'on le compare au midazolam, le propofol exagére aussi la dépression respiratoire induite par les morphiniques, mais à un moindre degré. L'incidence de l'hypoxémie constatée sous l'association propofol-fentanyl n'est que la moitié de celle qu'on observe sous midazolam-alfentanil. ${ }^{28}$

Présentement sous investigation, le rémifentanil, un analgésique morphinique, est métabolisé par des estérases tissulaires non spécifiques ce qui lui donne une demivie d'élimination de 8 à $12 \mathrm{~min}$. Bien que le rémifentanil soit capable de produire tous les effets secondaires propres aux morphiniques, sa courte durée d'action peut réduire les conséquences cliniques de ses effets indésirables. Des études préliminaires suggèrent qu'une perfusion de rémifentanil $0,1-0,15 \mu \mathrm{g} \cdot \mathrm{kg}^{-1} \cdot \mathrm{min}^{-1}$ produit une sédation et une sensation de bien-être très satisfaisantes avec une analgésie de fond efficace. ${ }^{30}$ Des études supplémentaires seront nécessaires pour déterminer si le rémifentanil est supérieur aux sédatifs-hypnotiques (par ex., le midazolam, le propofol) et aux analgésiques (par ex., le fentanyl, l'alfentanil) actuels et pour évaluer ses interactions avec les sédatifs-hypnotiques courants.

\section{Les anti-inflammatoires non stéroïdiens (AINS)}

Le problème des effets secondaires indésirables associés aux morphiniques en usage présentement a provoqué un regain d'intérêt pour les analgésiques non opiacés. ${ }^{31}$ Le kétorolac est un AINS puissant, actif par la voie parentérale et de plus en plus populaire pour supplémenter l'analgésie pendant l'anesthésie locale. La qualité de l'analgésie per- et postopératoire que le kétorolac procure est identique à celle du fentanyl, $3 \mu \mathrm{g} \cdot \mathrm{kg}^{-1}$, quand du kétorolac, $1 \mathrm{mg} \cdot \mathrm{kg}^{-1} \dot{\boldsymbol{i}}$, est administré à sa place comme seul appoint à l'anesthésie locale pendant des interven- 
tions chirurgicales mineures. ${ }^{32} \mathrm{Ce}$ qui est plus important, le kétorolac réduit considérablement l'incidence du prurit, des nausées et des vomissements. Il est intéressant de noter que d'autres investigateurs ont rapporté une incidence très basse de nausées quand des doses plus faibles d'analgésiques opiacés et non opiacés sont utilisées en association avec une perfusion de propofol pendant l'anesthésie locale. ${ }^{4}$ Bien que l'ajout de kétorolac soit suivi de moins de sédation postopératoire et permette un congé hospitalier un peu plus rapide, les patients traités au kétorolac reçoivent des doses plus élevées de propofol pour la sédation et sont plus susceptibles de requérir une analgésie supplémentaire pendant lintervention que ceux qui reçoivent du fentanyl.

\section{Les agonistes $\alpha_{2}$}

Les agonistes $\alpha_{2}$ dont la clonidine et la dexmédétomidine ont des propriété sédatives, anxiolytiques et un effet d'épargne analgésique considérables. Chez l'animal, l'augmentation de l'effet hypnotique du midazolam par la clonidine est comparable a celui que produit la morphine ${ }^{33}$ et elle pourrait devenir un adjuvant utile pendant la GAM. La dexmédétomidine est un agoniste alpha ${ }_{2}$ plus sélectif et plus puissant que la clonidine. Administrée avant l'anesthésie régionale intraveineuse pour la chirurgie de la main, la dexmédétomidine diminue le niveau d'anxiété et réduit le besoin d'analgésiques supplémentaires comparativement au groupe contrôle. ${ }^{34}$ En réalité, les patientes ambulatoires soumises à une intervention gynécologique récupèrent plus rapidement des effets sédatifs et anxiolytiques de la dexmédétomidine. ${ }^{35}$ Cependant, la dexmédétomidine est associée à une incidence élevé de bradycardie, ce qui pourrait en limiter l'usage. ${ }^{34,36}$ Des études futures sont requises pour définir la place des agonistes alpha ${ }_{2}$ en pratique anesthésique moderne.

\section{Les antagonistes}

L'arrivée d'un antagoniste spécifique des benzodiazépines, le flumazénil, offre la possibilité de diminuer la sédation résiduelle postopératoire et l'amnésie causées par le midazolam, sans augmenter pour autant la niveau d'anxiété du patient. ${ }^{37}$ L'administration de flumazénil, $1 \mathrm{mg} i v$, après une chirurgie mineure effectuée sous anesthésie locale avec sédation au midazolam permet de libérer le patient environ $20 \mathrm{~min}$ plus tôt que le patient du groupe contrôle qui a reçu un placebo (Figure 4). ${ }^{38}$ Le flumazénil réduit aussi l'incidence et la durée de l'amnésie postopératoires sans augmenter l'incidence de l'évocation des événements peropératoires. L'association midazolamflumazénil est identique à une association comportant du propofol au regard de la durée de la récupération aussi bien que de l'amnésie per- et postopératoire. ${ }^{38}$ Cependant, le flumazénil possède une durée d'action courte (avec une

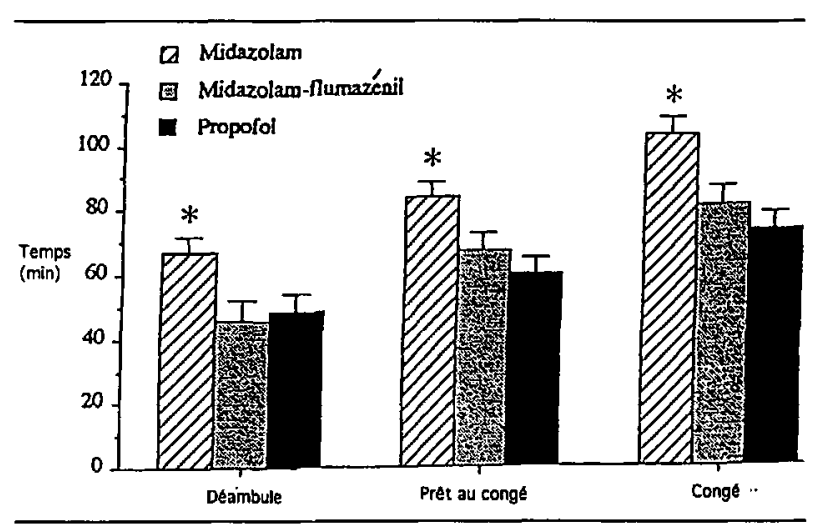

FIGURE 4 Durées de récupération après la chirurgie sous anesthésie locale et sédation au midazolam (moyenne $10 \mathrm{mg}$ ) chez les patients qui reçoivent du flumazénil, $1 \mathrm{mg}$ (barres pleines), et un groupe contrôle (barres vides). Les valeurs représentent la moyenne \pm SEM. Adapté avec permission de Ghouri et al. ${ }^{2} * P<0,05$ comparaison avec groupe contrôle.

demi-vie délimination de $60-90 \mathrm{~min}$ ), ce qui peut favoriser une réapparition tardive de la sédation à la période postopératoire. Par contre, après le propofol, une fois le réveil complété, le retour de la sédation est extrêmement rare. Par conséquent, bien que le renversement par le flumazénil de la sédation et de l'amnésie induites par les benzodiazépines soit comparable à une technique à base de propofol, il est peu plausible que le flumazénil soit un jour utilisé régulièrement après des interventions sous GAM. Par ailleurs, le flumazénil pourrait réduire les coûts hospitaliers chez les patients qui ont reçu de trop fortes doses de benzodiazépines pour de brèves interventions diagnostiques (par ex., les bronchoscopies) aussi bien que pour le traitement de patients qui ont reçu inopinément une surdose de benzodiazépine.

\section{L'association de modes de sédation}

Dépendant des besoins individuels et du type dintervention, les degrés d'amnésie, d'anxiolyse, de sédation et d'analgésie varient pendant l'anesthésie locorégionale. Bien que le propofol produise une sédation constante et facilement contrôlable avec un réveil rapide, il est relativement exempt de propriétés amnésiques et analgésiques. ${ }^{25}$ Au contraire, le midazolam est un excellent agent anxiolytique et amnésique mais il est moins facilement titrable et procure une récupération plus lente. En combinant une petite dose de midazolam avec une perfusion de propofol continue et à bas débit, il est possible d'associer les effets bénéfiques des deux agents sans compromettre le réveil. ${ }^{39}$ En pratique, en faisant précéder une perfusion de propofol à débit variable avec du midazolam ( $2 \mathrm{mg} \dot{i v}$ ), on réduit l'anxiété tout en augmentant le score de sédation et d'amnésie des événements peropératoires comparativement à un groupe contrôle qui ne reçoit que 


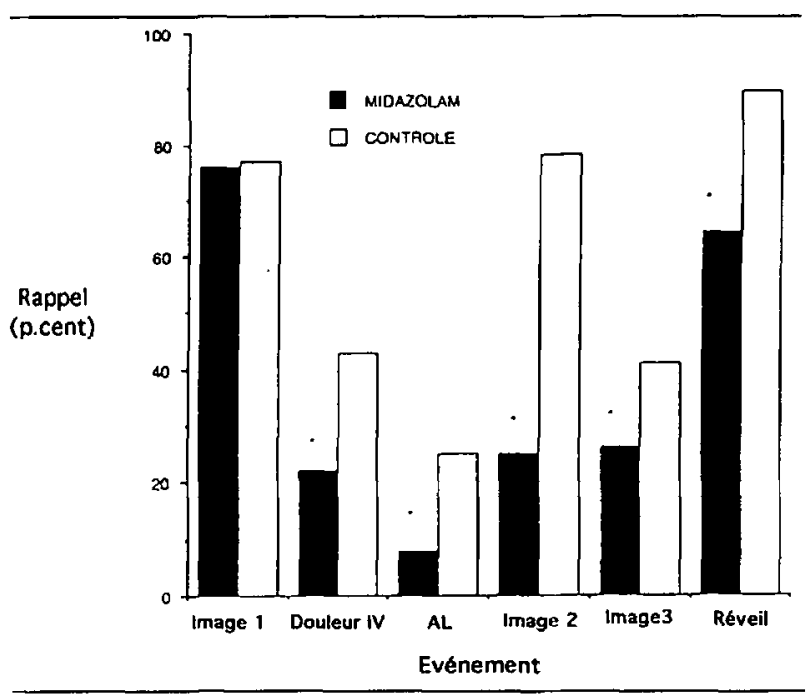

FIGURE 5 Rappel des événements à la période périopératoire chez les patients qui reçoivent soit du midazolam $(2 \mathrm{mg}, \dot{v})$ ou du physiologique $(2 \mathrm{ml})$ avant une sédation avec une perfusion au propofol. Les événements spécifiques sont: 1) une image exhibée 3-5 min après l'administration de la drogue étudiée, 2) la douleur à l'injection du propofol, 3) une image montrée au moment de l'incision de la peau, 5) une image montrée à la fin de la chirurgie et 6) une image montré à la salle de réveil. Reproduit avec la permission de Taylor et al. ${ }^{39} * P<0,05$ du groupe sol. physiologique.

la perfusion à débit variable de propofol (Figure 5). ${ }^{39}$ En outre, l'atteinte de critères de réveil prédéterminés n'est pas retardée par l'utilisation de la technique de sédation conjointe midazolam-propofol. Il est important de noter que la petite dose de midazolam ne provoque pas de dépression respiratoire même lorsque du fentanyl est administré pour procurer un supplément d'analgésie pendant les injections de l'analgésique local. D'autres investigateurs ont aussi décrit l'effet bénéfique des associations de midazolam, de propofol et de morphiniques pour renforcer l'anesthésie pendant des manoeuvres douloureuses. $^{28,40}$

\section{La sédation autocontrôlée}

A cause des importantes variations individuelles de sensibilité aux sédatifs-hypotiques, il est difficile de procurer une niveau optimal de sédation à tous les patients pendant la GAM. En outre, les patients ont des préférences personnelles quant au degré de sédation quills désirent pendant la chirurgie, degré qui varie entre l'état vigile et la sédation profonde (proche de lhypnose) avec amnésie complète. Au cours d'une intervention, les niveaux de stimulation et d'inconfort peuvent aussi changer, de sorte qu'à différents moments, des niveaux distincts de sédation peuvent être requis. Devant ce dilemme, une solution s'offre à nous: permettre aux patients de s'administrer eux-mêmes la médication, en adaptant la séda- tion et l'analgésie à leurs besoins individuels. La popularité croissante de l'analgésie autocontrôlée (PCA) a permis le développement plusieurs types de pompes à perfusion destinées spécifiquement à cette fonction. Pendant le recouvrement transvaginal d'un ovule (intervention caractérisée par des stimulation intermittentes douloureuses), Zelcer et al. ont procuré l'analgésie avec du fentanyl autoadministré ou administré par l'anesthésiste. ${ }^{41}$ Des doses identiques d'alfentanil sont requises par les deux groupes de patientes et des scores de douleur et de confort sont enregistrés pendant l'intervention. La stabilité hémodynamique, les effets secondaires périopératoires et la satisfaction des patientes sont les mêmes dans les deux groupes.

Un dispositif d'autoperfusion peut être utilisé pour la sédation autocontrôlée (SCP). Pendant l'anesthésie épidurale, les patients qui s'administrent eux-mêmes un mélange de midazolam-fentanyl décrivent un degré plus élevé de confort malgré des doses de sédatif identiques à celle que reçoivent les patients du groupe contrôle. ${ }^{42}$ Le propofol est administré avec un système de SCP. Les patients rapportent un niveau élevé de satisfaction avec un bolus de propofol de $0,7 \mathrm{mg} \cdot \mathrm{kg}^{-1}$ et un intervalle de sécurité de trois minutes pendant des extractions dentaires $^{53}$ ou en association avec un anesthésie épidurale. Comparativement au fentanyl-midazolam administré par un anesthésiste, les patients qui s'administrent eux-mêmes du propofol sont plus satisfaits et démontrent une meilleure fonction cognitive en postopératoire ${ }^{45}$ Cependant, ces différences pourraient être dues au propofol (vs midazolam) plutôt qu’à la SCP elle-même. Après une prémédication au midazolam, $2 \mathrm{mg}$, et au fentanyl, 50 $\mu \mathrm{g}$, le propofol, le midazolam et l'alfentanil administrés par un système SCP, on tous produit une degré de satisfaction élevé pendant la chirurgie sous anesthésie locale. ${ }^{46}$ Cependant, le propofol est associé à moins de nausées postopértoires que ne l'est l'alfentanil, et le midazolam produit une amnésie peropératoire plus puissante et moins de douleur à l'injection que le propofol. La participation du patient est plus importante avec la SCP; la sécurité inhérente à la rétroaction directe pourrait à l'avenir mener à l'augmentation de l'utilisation des techniques de sédation autocontrôlée.

\section{Résumé}

L'anesthésie locale gagne en popularité à cause de l'amélioration de son profil de récupération comparativement à l'anesthésie générale et régionale (Tableau II). ${ }^{1,2,28,47,48}$ L'utilisation d'adjuvants intraveineux pendant l'anesthésie locorégionale peut améliorer le confort du patient tout en optimisant les conditions opératoires. Ces techniques sédatives-hypnotiques sont de plus applicables à des interventions pour lesquelles un anesthésique local n'est ni 
nécessaire ni possible. Alors que les associations à base d'anesthésique local sont en général perçues comme plus sûres que l'anesthésie générale, l'ajout de puissants sédatifs hypnotiques et d'analgésiques peut déprimer considérablement l'effort respiratoire ${ }^{7}$ et/ou produire une obstruction des voies aériennes. ${ }^{17}$ Bien que des perfusions de sédatifs rapides et de courte durée titrées minutieusement puissent augmenter la sécurité du patient, des études supplémentaires sont nécessaires pour déterminer le système d'administration optimal pour les adjuvants intraveineux. ${ }^{49}$ Pour réaliser les résultats désirés, nous avons besoin d'un monitorage vigilant avec un supplément d'oxygène et l'accès immédiat à de l'équipement de réanimation. Les soucis causés par l'augmentation des coûts des soins de santé nous forcent à évaluer la balance coût-bénéfice de tous les nouveaux produits sédatifs et analgésiques et leurs techniques d'administration. Récemment, Kain et al. ${ }^{50}$ rapportent que financièrement, le propofol est préférable aux barbituriques peu coûteux lorsqu'on l'utilise en dehors de la salle d'opération à cause de son profil de récupération plus favorable. Pour conclure, l'accès à de nouveaux produit sédatifs et analgésiques possèdant une activité plus spécifique, des durées d'action plus courtes et moins d'effets secondaires ainsi que de nouvelles techniques comme la SCP devraient améliorer à l'avenir la sécurité et le confort du patient pendant l'anesthésie locorégionale.

\section{Références}

(Voir page R45) 